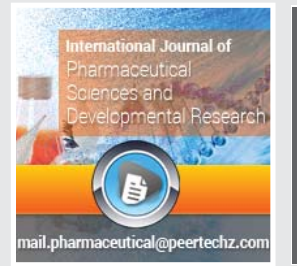

\section{Validation of}

\section{spectrophotometric \\ method for determination}

of esomeprazole and

\section{ciprofloxacin in their pure and} dosage forms

\author{
Mohsen M Zareh ${ }^{1}$, Monir Z Saad ${ }^{1}$, Wafaa S Hassan², \\ Mostafa E Elhennawy ${ }^{1}$ and Mahmoud M Sebaiy ${ }^{3 *}$ \\ 'Department of Chemistry, Faculty of Science, Zagazig University, Zagazig, Egypt \\ ${ }^{2}$ Department of Analytical Chemistry, Faculty of Pharmacy, Zagazig University, Zagazig, Egypt \\ ${ }^{3}$ Department of Medicinal Chemistry, Faculty of Pharmacy, Zagazig University, Zagazig, Egypt
}

ISSN: $2640-7760$

DOI: https://dx.doi org/10.17352/ijpsdr
Received: 07 January, 2019

Accepted: 28 January, 2020

Published: 29 January, 2020

*Corresponding author: Mahmoud M Sebaiy, Department of Medicinal Chemistry, Faculty of Pharmacy, Zagazig University, Zagazig, Egypt,

E-mail:mmsebaiy@zu.edu.eg; sebaiym@gmail.com

Keywords: Spectrophotometric; Esomeprazole; Ciprofloxacin; $\mathrm{KMnO4}$; ICH guidelines

https://www.peertechz.com

Check for updates

\begin{abstract}
A novel simple, accurate, sensitive and economical spectrophotometric method has been established and validated for the determination of esomeprazole and ciprofloxacin. The method is based on the oxidation of the studied drug by a known excess of potassium permanganate, followed by measuring the decrease in absorption $(\Delta \mathrm{A})$ of $\mathrm{KMnO}_{4}$ in acidic medium at wavelength of $525 \mathrm{~nm}$. The detection limit is reported to be 1.01 and $1.06 \mu \mathrm{g} / \mathrm{mL}$ showing a high degree of sensitivity. The proposed method was successfully validated according to $\mathrm{ICH}$ guidelines for the determination of esomeprazole and ciprofloxacin with a highly precise recovery and very low relative standard deviation. Finally, the method was compared statistically with a reference method showing equal accuracy, reproducibility and no significant difference with the reported one.
\end{abstract}

\section{Introduction}

Esomeprazole (ESM) (Figure 1) is chemically, 5-methoxy$2-\{[(4-$ methoxy-3,5-dimethylpyridin-2-yl)methyl $]$ sulfinyl $\}-1 \mathrm{H}$-benzimidazole that has $\mathrm{S}$ configuration at the sulfur atom. It is a proton pump inhibitor that decreases the amount of acid produced in the stomach. ESM is used to treat certain stomach and esophagus problems. It relieves symptoms such as heartburn, difficulty swallowing, and persistent cough. This medication helps heal acid damage to the stomach and esophagus, helps prevent ulcers, and may help prevent cancer of the esophagus [1]. ESM is combined with the antibiotics, clarithromycin and amoxicillin (or metronidazole in penicillin-hypersensitive patients) in the 7-14days eradication triple therapy for Helicobacter pylori. Infection by H. pylori is the causative factor in the majority of peptic and duodenal ulcers [2]. Literature survey demonstrated that few analytical techniques have been employed for the determination of ESM<smiles></smiles>

ESM

CIP

Figure 1: Chemical structures of esomeprazole (ESM) and ciprofloxacin (CIP). 
such as spectrophotometry [1-8], liquid chromatography $[8,9]$ and spectrodensitometry method [10].

Ciprofloxacin (CIP) (Figure 1) is 1-cyclopropyl-6-fluoro4-oxo-7-piperazin-1-ylquinoline-3-carboxylic acid. It is used to treat a variety of bacterial infections. CIP belongs to a class of drugs called quinolone antibiotics. It works by stopping the growth of bacteria [11]. Literature survey demonstrated that several analytical techniques have been employed for the determination of CIP such as different spectroscopic [11-14] and chromatographic [15-18] methods.

To our knowledge, no spectrophotometric method for the determination of ESM or CIP using potassium permenganate as an oxidant has yet been reported despite the versatility, simplicity and reliability of the technique in chemical analysis. As such, in this paper, the method is based on an oxidation reaction of ESM and CIP with a known excess of $\mathrm{KMnO}$ followed by measuring the decrease in absorption $(\Delta \mathrm{A})$ of $\mathrm{KMnO}_{4}$ in acidic medium at wavelength of $525 \mathrm{~nm}$.

\section{Experimental}

\section{Apparatus}

Labomed $^{\circledR}$ Spectro UV-VIS Double Beam (UVD-2950) Spectrophotometer with matched $1 \mathrm{~cm}$ quartz cells and connected to windows compatible computer using UV Win 5 Software v5.0.5.

\section{Materials and reagents}

All solvents and reagents were of analytical grade and double distilled water was used throughout the work. Esomeprazole was kindly provided by, Copad pharma for pharmaceutical industries, Obour City, Egypt. Standard solution of $200 \mu \mathrm{g} / \mathrm{mL}$ was prepared by dissolving $(0.02 \mathrm{~g})$ of the pure drug in $100 \mathrm{~mL}$ double distilled water. Ciprofloxacin was kindly provided by, Egyptian Company for Pharmaceutical \& Chemical Industries (EIPICO), $10^{\text {th }}$ Of Ramadan City, Egypt. Standard solution of $200 \mu \mathrm{g} / \mathrm{mL}$ was also prepared by dissolving $(0.02 \mathrm{~g})$ of the pure drug in 100mL double distilled water. Potassium Permanganate (Aldrich Chemical Co. Ltd., Dorset, England), Standard solution of $5.0 \times 10^{-3} \mathrm{M}$, was prepared by dissolving $(0.079 \mathrm{~g})$ of the $\mathrm{KMnO}_{4}$ in $100 \mathrm{~mL}$ double distilled water and stored in dark bottle. Sulfuric Acid (El-nasr chemical, Egypt) was prepared as $2 \mathrm{M}$.

\section{Pharmaceutical formulations}

Esmatac $^{\circledR} 40 \mathrm{mg}$ was labeled to contain $40 \mathrm{mg}$ esomeprazole (Egyptian group for pharmaceutical industries). Ciprocin ${ }^{\circledR}$ 250mg was labeled to contain 250mg ciprofloxacin (Egyptian Company for Pharmaceutical \& Chemical Industries (EIPICO)).

\section{Spectrophotometric procedures}

Construction of the standard calibration curves: Aliquot portions of $200 \mu \mathrm{g} / \mathrm{mL}$ ESM and CIP ranging from $(0.40-2 \mathrm{ml})$ were transferred into a series of $10 \mathrm{~mL}$ measuring flasks. To these, $1 \mathrm{~mL}$ and $1.50 \mathrm{~mL}$ of $2 \mathrm{M}$ sulfuric acid were added for both ESM and CIP respectively, then $1 \mathrm{~mL}$ of $5 \times 10^{-3} \mathrm{M} \mathrm{KMnO}_{4}$ were added to both drugs then the total volume was adjusted to $10 \mathrm{~mL}$ with double distilled water. The absorbance of a reagent blank (similarly prepared without the drug) was measured against each drug concentration at $525 \mathrm{~nm}$ either immediately in case of ESM or after 16minutes in case of CIP.

Procedure for pharmaceutical preparations: Accurately weights of Esmatac ${ }^{\circledR}$ 40mg equal to 20mg of ESM or Ciprocin ${ }^{\circledR}$ $250 \mathrm{mg}$ equal to $20 \mathrm{mg}$ of CIP were transferred to a $100 \mathrm{~mL}$ measuring flask and completed to volume with double distilled water to give an equivalent final concentration of $200 \mu \mathrm{g} / \mathrm{mL}$. The procedures were then conducted as mentioned above under the general procedures applying standard addition techniques.

\section{Results and discussions}

\section{Optimization of the reaction conditions}

The optimum conditions for the method development were established by varying each specific parameter and keeping the others constant and observing the effect produced on the absorbance of the colored species. The optimum parameters are reported in Table 1.

Absorption spectra: Absorption spectra of ESM and CIP with $\mathrm{KMnO}_{4}$ was studied over a range of $400-800 \mathrm{~nm}$. Potassium permanganate reacts with ESM and CIP in acidic medium and the decrease in absorption can be measured at $525 \mathrm{~nm}$ as depicted in Figure 2.

\section{Effect of temperature}

Effect of temperature was studied and results showed that there is no an evident effect of temperature on the reaction as increase in temperature is not accompanied with any increase in absorbance and so, optimum reaction was performed at room temperature.

Table 1: Analytical parameters and spectrophotometric characteristics of the proposed method for ESM and CIP determination.

\begin{tabular}{|c|c|c|}
\hline parameters & ESM & CIP \\
\hline$\lambda_{\max }$ & \multicolumn{2}{|c|}{$525 \mathrm{~nm}$} \\
\hline Volume of the media $\left(2 \mathrm{M} \mathrm{H}_{2} \mathrm{SO}_{4}\right.$ & $1 \mathrm{ml}$ & $1.50 \mathrm{ml}$ \\
\hline Volume of the reagents $\left(\mathrm{KMnO}_{4}\right.$ & \multicolumn{2}{|c|}{$1 \mathrm{ml}$} \\
\hline Time of reaction between drug and $\mathrm{KMnO}_{4}$ & immediate & 16 minutes \\
\hline Temperature & \multicolumn{2}{|c|}{ Ambient } \\
\hline
\end{tabular}

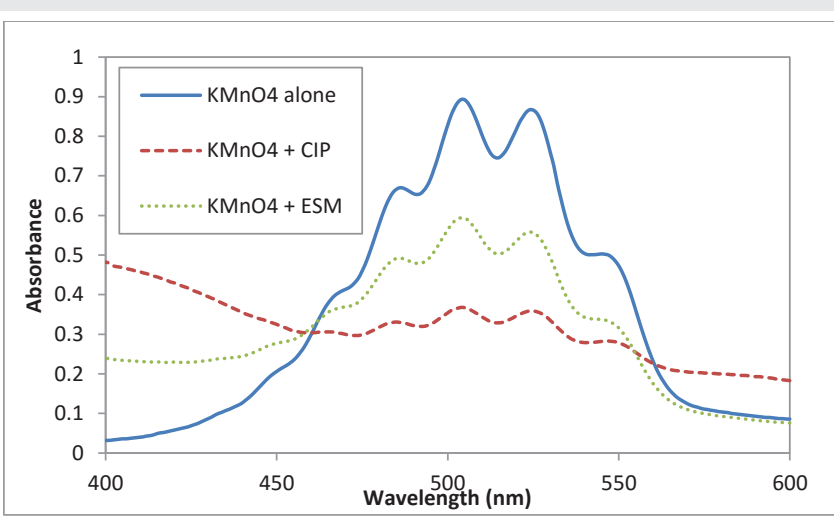

Figure 2: Absorption spectra of $\mathrm{KMnO} 4$ either alone (blue line), or with ESM (green dotted line) or with CIP (red dashed line) in acidic medium at $525 \mathrm{~nm}$. 
Effect of addition sequence: Addition sequences were studied and results revealed that the most appropriate sequence was the drug then the added acid then the added $\mathrm{KMnO}_{4}$.

Effect of acidity : To study the effect of sulfuric acid volume, the reaction was performed in a series of $10 \mathrm{~mL}$ volumetric flasks containing different volumes $(0.5-4 \mathrm{ml})$ of $2 \mathrm{M}$ sulfuric acid. It was found that the maximum absorbance was obtained when using $1 \mathrm{~mL}$ of $2 \mathrm{M}$ sulfuric acid with ESM and $1.50 \mathrm{~mL}$ with CIP as seen in Figure 3.

Effect of permenganate concentration: By studying the effect of $\mathrm{KMnO}_{4}$ concentration referring to decrease of its color intensity, it was observed that the absorbance reached its maximum when $1 \mathrm{~mL}$ of $5 \times 10^{-3} \mathrm{M} \mathrm{KMnO}_{4}$ was used in case of both ESM and CIP (Figure 4).

Effect of time: The effect of time on the oxidation reaction was studied to obtain the highest and most stable absorbance. As depicted in Figure 5, This absorbance can be achieved immediately after the reaction between the drug and $\mathrm{KMnO}_{4}$ in case of ESM while it takes 16 minutes in case of CIP to complete the reaction.

\section{Method validation}

The method validation was performed according to International Conference of Harmonization (ICH) guidelines [19]

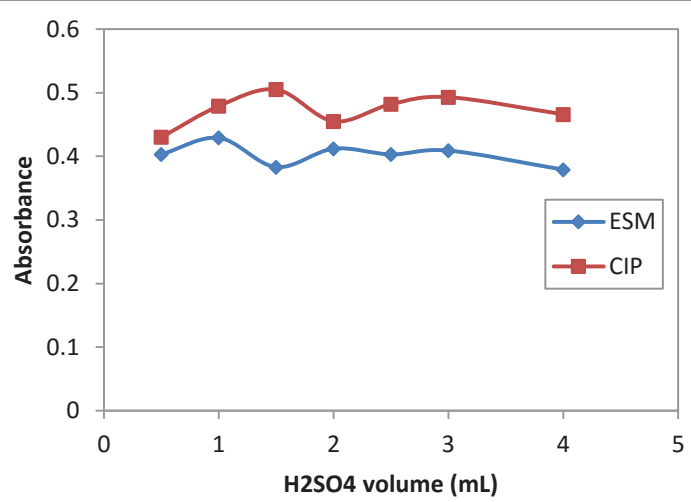

Figure 3: Effect of acidity on the reaction of $\mathrm{KMnO}_{4}$ with ESM (blue) or with CIP (red) at $525 \mathrm{~nm}$.

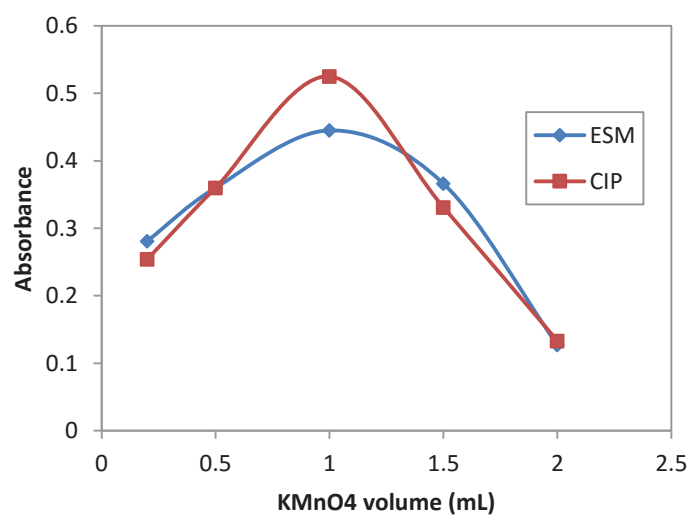

Figure 4: Effect of volume of $\mathrm{KMnO}_{4}$ with ESM (blue) or with CIP (red) in acidic medium at $525 \mathrm{~nm}$.

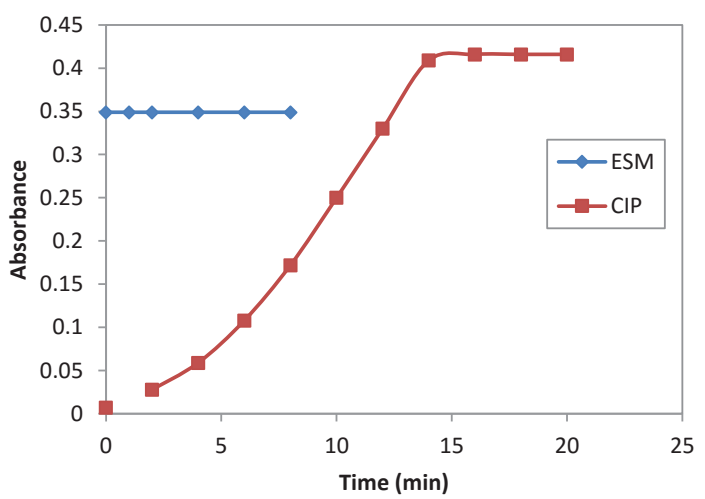

Figure 5: Effect of time on the reaction of $\mathrm{KMnO}_{4}$ with $\mathrm{ESM}$ (blue) or with CIP (red) in acidic medium at $525 \mathrm{~nm}$.

Linearity: Six different concentrations of ESM and CIP were prepared for linearity studies. The linearity ranges of absorbance as a function of drug concentration (Table 2) provided acceptable indication about sensitivity of reagents used. Linear regression equations of ESM and CIP were found to be $\mathrm{y}=0.0334 \mathrm{x}+0.0379$ and $\mathrm{y}=0.0444 \mathrm{x}+0.2459$, respectively and the regression coefficient values $\left(\mathrm{R}^{2}\right)$ were found to be 0.9994 and 0.9991 , respectively indicating a high degree of linearity for both drugs (Figure 6).

Accuracy: The accuracy of the method was determined by investigating the recovery of ESM and CIP concentration levels covering the specified range using the standard addition technique. It was performed by adding a fixed standard drug concentration at different levels of the pharmaceutical products (Esmatac ${ }^{\circledR}$ and Ciprocin ${ }^{\circledR}$ ) and the proposed method was followed. From the amount of the drug estimated, the percentage recovery was calculated and the results are shown in Table 3.

Specificity: The specificity studies revealed that the presence of the excipents in Esmatac ${ }^{\circledR}$ 40mg and Ciprocin ${ }^{\circledR}$ 250mg formulations didn't show any kind of impurity interference, since the recoveries lied in the range of 96.90$104.85 \%$ as reported in Table 3.

Limits of detection and limits of quantification: The calculation of limits of detection and quantitation was based on the following equations: $\mathrm{LOD}=3.3 \mathrm{~S} / \mathrm{K}$ and $\mathrm{LOQ}=10 \mathrm{~S} / \mathrm{K}$, respectively, where $\mathrm{S}$ is the standard deviation of the seven replicate values under the same conditions as for the sample analysis in the absence of analyte and $\mathrm{K}$ is the sensitivity, namely, the slope of calibration graph. Limits of detection were calculated to be 1.01 and $1.06 \mu \mathrm{g} / \mathrm{mL}$ while limits of quantification were 3.35 and $3.55 \mu \mathrm{g} / \mathrm{mL}$, for ESM and CIP respectively (Table 2 ).

Robustness: The robustness of the method was evaluated by making small changes $( \pm 0.05 \mathrm{ml})$ in the volume of $\mathrm{H}_{2} \mathrm{SO}_{4}$ and $\mathrm{KMnO}_{4}$ keeping the other conditions constant where the effect of the changes was studied on the percent recovery and standard deviation of $20 \mu \mathrm{g} / \mathrm{mL}$ ESM and CIP. The changes had negligible influence on the results where SD values were in the acceptable range as reported in Table 4 . 
Ruggedness: The ruggedness of the method was tested by measuring three concentrations of the standard working solution using a different double beam spectrophotometer (model Jenway 6500, UK). The absorbances in case of the three procedures for both instruments were exactly similar indicating that the method is fairly rugged. According to ICH guidelines, the obtained values indicated high sensitivity of the proposed method.

\section{Statistical analysis of the pharmaceutical formulation}

Esmatac ${ }^{\circledR} 40 \mathrm{mg}$ and Ciprocin ${ }^{\circledR} 250 \mathrm{mg}$ have been successfully analyzed by the proposed method. Results obtained were compared to those obtained by applying reference methods $[4,11]$ where Student's t-test and F-test were performed for comparison. Results are shown in table 5 where the calculated $\mathrm{t}$ and $\mathrm{F}$ values were less than tabulated values at $p=0.05$, which in turn indicate that there is no significant difference between proposed method and reference one relative to precision and accuracy.

\section{Conclusion}

Unlike GC and HPLC techniques, spectrophotometry is simple and inexpensive. The proposed oxidation- reduction

Table 2: Results of the analysis for determination of ESM and CIP in pure samples using the proposed method.

\begin{tabular}{|c|c|c|c|c|c|c|}
\hline \multirow[b]{2}{*}{ parameters } & \multicolumn{3}{|c|}{ ESM } & \multicolumn{3}{|c|}{ CIP } \\
\hline & 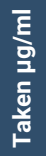 & $\begin{array}{l}\bar{\Xi} \\
\text { 을 } \\
\text { 을 } \\
\text { 욘 }\end{array}$ & 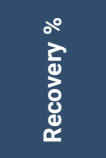 & 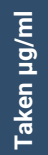 & $\begin{array}{l}\overline{\mathbf{g}} \\
\text { 을 } \\
\text { 몸 } \\
\text { 운 }\end{array}$ & 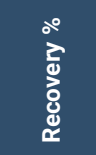 \\
\hline & 5 & 5.032 & 100.658 & 4 & 3.898 & 97.466 \\
\hline & 8 & 8.146 & 101.833 & 8 & 8.132 & 101.661 \\
\hline & 10 & 10.002 & 100.029 & 12 & 11.894 & 99.117 \\
\hline & 14 & 13.775 & 98.396 & 14 & 14.033 & 100.241 \\
\hline & 16 & 16.05 & 100.318 & 16 & 16.195 & 101.224 \\
\hline & 20 & 20.122 & 100.613 & 18 & 17.795 & 98.861 \\
\hline Mean & & & 100.308 & & & 99.762 \\
\hline $\pm S D$ & & & 1.12 & & & 1.579 \\
\hline$\pm \mathrm{RSD}$ & & & 1.117 & & & 1.583 \\
\hline $\pm S E$ & & & 0.457 & & & 0.644 \\
\hline Variance & & & 1.255 & & & 2.494 \\
\hline Slope & & & 0.033 & & & 0.044 \\
\hline LOD & & & 1.01 & & & 1.06 \\
\hline LOQ & & & 3.35 & & & 3.55 \\
\hline
\end{tabular}

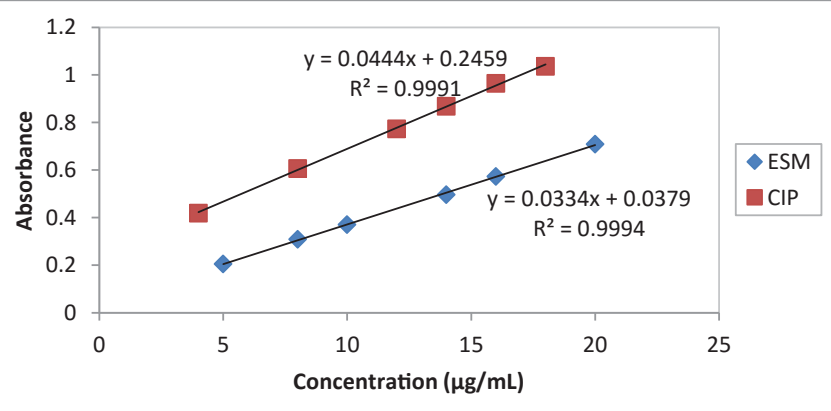

Figure 6: Calibration curves of ESM and CIP using the proposed method.
Table 3: Application of standard addition technique for the determination of Esmatac $^{\circledast} 40 \mathrm{mg}$ and Ciprocin ${ }^{\circledast} 250 \mathrm{mg}$ using the proposed method.

\begin{tabular}{|c|c|c|c|c|c|c|c|c|}
\hline \multirow[b]{2}{*}{ parameters } & \multicolumn{4}{|c|}{ ESM } & \multicolumn{4}{|c|}{ CIP } \\
\hline & 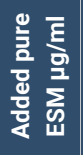 & 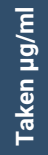 & 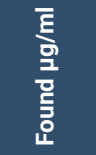 & 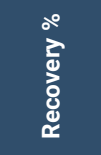 & 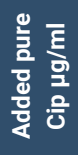 & 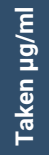 & 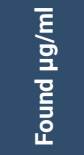 & 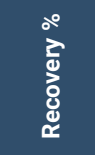 \\
\hline & 2 & 3 & 5.242 & 104.85 & 2 & 2 & 3.876 & 96.903 \\
\hline & 2 & 6 & 7.937 & 99.214 & 2 & 6 & 7.997 & 99.971 \\
\hline & 2 & 8 & 10.212 & 102.125 & 2 & 10 & 11.781 & 98.179 \\
\hline & 2 & 12 & 14.404 & 102.887 & 2 & 12 & 14.304 & 102.171 \\
\hline & 2 & 14 & 16.35 & 102.189 & 2 & 14 & 16.578 & 103.617 \\
\hline & 2 & 18 & 20.332 & 101.661 & 2 & 16 & 18.065 & 100.362 \\
\hline Mean & & & & 102.154 & & & & 100.201 \\
\hline $\pm S D$ & & & & 1.827 & & & & 2.473 \\
\hline $\pm R S D$ & & & & 1.788 & & & & 2.468 \\
\hline $\pm S E$ & & & & 0.745 & & & & 1.009 \\
\hline Variance & & & & 3.339 & & & & 6.119 \\
\hline
\end{tabular}

Table 4: Results of the robustness for $16 \mu \mathrm{g} / \mathrm{mL}$ CIP and ESM samples using the proposed method.

\begin{tabular}{|c|c|c|c|c|c|c|}
\hline $\begin{array}{c}\text { Procedure/ } \\
\text { Parameter } \\
\text { changes }\end{array}$ & $\begin{array}{c}\text { Mean } \\
\text { recovery } \pm \mathrm{SD}\end{array}$ & $\begin{array}{c}\mathrm{CV} \\
(\%)\end{array}$ & $\begin{array}{c}\% \\
\text { Accuracy }\end{array}$ & $\begin{array}{c}\text { Mean } \\
\text { recovery } \pm \mathrm{SD}\end{array}$ & $\begin{array}{c}\mathrm{CV} \\
(\%)\end{array}$ & $\%$ Accuracy \\
\hline$+0.05 \mathrm{~mL} \mathrm{H}_{2} \mathrm{SO}_{4}$ & $101.24 \pm 3.15$ & 1.24 & 1.24 & $102.15 \pm 6.91$ & 2.15 & 2.153 \\
\hline $\begin{array}{c}-0.05 \mathrm{~mL} \mathrm{H}_{2} \mathrm{SO}_{4} \\
+0.05 \mathrm{~mL}^{-100.87 \pm 2.28}\end{array}$ & 0.87 & 0.87 & $101.8 \pm 6.01$ & 1.78 & 1.779 \\
\hline $\begin{array}{c}\mathrm{KMnO}_{4} \\
-0.05 \mathrm{~mL} \mathrm{KMnO}_{4}\end{array}$ & $102.2 \pm 5.54$ & 2.24 & 2.2 & $98.3 \pm 2.92$ & -1.69 & -1.7 \\
\hline
\end{tabular}

Table 5: Statistical analysis of results obtained by the proposed method applied on Esmatac ${ }^{\circledR} 40 \mathrm{mg}$ and Ciprocin ${ }^{\circledR} 250 \mathrm{mg}$ dosage forms compared with reference methods.

\begin{tabular}{|c|c|c|c|c|}
\hline Parameters & $\begin{array}{c}\text { Proposed method } \\
\text { (ESM) }\end{array}$ & $\begin{array}{l}\text { Reported } \\
\text { method [4] }\end{array}$ & $\begin{array}{c}\text { Proposed } \\
\text { method (CIP) }\end{array}$ & $\begin{array}{l}\text { Reported } \\
\text { method [11] }\end{array}$ \\
\hline $\mathrm{N}$ & 6 & 5 & 3 & 5 \\
\hline $\begin{array}{c}\text { Mean } \\
\text { Recovery }\end{array}$ & 102.154 & 100.10 & 99.50 & 99.64 \\
\hline SE & 0.745 & 0.87 & 0.67 & 0.22 \\
\hline Variance & 3.339 & 3.82 & 1.35 & 0.25 \\
\hline Student-t** & $1.80(1.83) a$ & $0.61(1.89) a$ & $0.23(1.94) a$ & \\
\hline F-test** & 1.14(5.19)b & $1.46(6.59) b$ & $5.35(6.94) b$ & \\
\hline
\end{tabular}

method requires reagents which are very cheap and readily available, no $\mathrm{pH}$ adjustment is required and the procedure does not involve any critical reaction conditions or tedious sample preparation. According to ICH guidlines, the method is simple, fast, accurate, sensitive, rugged and free from interference by excipients which makes it ideal for routine quality control analysis. The amounts obtained by the proposed method for pharmaceutical products lied in the acceptable range of $96.90-104.85 \%$ and were statistically superior to the reference methods with respect to both sensitivity and selectivity.

\section{Ethical approval}

This manuscript does not include any studies on human or animals. 


\section{References}

1. Mohan Raj P, Veeresara Rao R, Mukherjee PB, Sarvanan VS, Gopal $\mathrm{N}$, et al. (2007) (2007) UV-Spectrophotometric Determination of Esomeprazole in Tablet Dosage Forms. Asian J Chem 19: 3250-3252. Link: http://bit.ly/2SaUJqH

2. Rachmale PM (2012) Analytical Method Development of Esomeprazole In Bulk And Single Component Formulation Int J Pharm Sci Res 5067-5074. Link: http://bit.ly/3aSIwzm

3. Nafisur R, Zehra B, Syed N, Hejaz Azmi SN (2008) Spectrophotometric Determination of Esomeprazole Magnesium in Commercial Tablets Using 5-Sulfosalicylic Acid and N-Bromosuccinimide. J Chinese Chem Society Taipei 55. Link: http://bit.ly/36DFADc

4. Shebina R, Sanal D, Remya K , Jemi J, Smitha R (2017) Determination of Esomeprazole by Complexation Method. Der Pharma Chemica 9. Link: http://bit.ly/2uGoZ4q

5. Lakshmana PS, Shirwaikar A, Annie Sh, Dinesh K, Joseph A, et al. (2008) Simultaneous Estimation of Esomeprazole and Domperidone by UV Spectrophotometric Method. Indian J Pharm Sci 70: 128-131. Link: http://bit.ly/36xducN

6. Neha AJ, Lohiya RT, Umekar MJ (2011) Spectrophotometric Determination Of Naproxen And Esomeprazole In a Laboratory Mixture By Simultaneous Equation, Absorption Correction, Absorption Ratio And Area Under Curve Methods. Int J Pharm Sci Res 2: 130-134. Link: http://bit.ly/2RZ8pVj

7. Makka HA, Mohamed E, Iqbal MCh, Shakil A, Saeed AEM (2017) Development And Validation Of Spectrophotometric Methods For The Determination of Esomeprazole Magnesium In Pharmaceutical Formulations. World Journal of Pharmacy And Pharmaceutical Sciences 6.

8. Mokhtar MM, Sherin FH, Fotouh RM, El-Khateeb BZ (2019) Simultaneous Determination of Diclofenac and Esomeprazole by Reversed phase Liquid Chromatography, Dual Wavelength and Derivative Spectrophotometry. J Anal Chem 74: 458-466. Link: http://bit.ly/3aLispP

9. Gosavi SM, Tayade MA (2017) Development and Validation of High Performance Thin Layer Chromatography for Determination of Esomeprazole Magnesium in Human Plasma. J Chromatogr Sep Tech 8. Link: http://bit.ly/2U5toJ1
10. Pakinaz YK, Hassan RH, Mohamed MEl (2017) Spectrodensitometric simultaneous determination of esomeprazole and domperidone in human plasma. Open Chem 15. Link: http://bit.ly/2RzYNBo

11. Mostafa S, El-Sadek M, Alla EA (2002) Spectrophotometric determination of ciprofloxacin, enrofloxacin and pefloxacin through charge transfer complex formation. J Pharm Biomed Anal 27: 133-142. Link: http://bit.ly/3aQSMYR

12. Edith CLC, Hérida RNS (2012) Spectrophotometric Determination of Ciprofloxacin Hydrochloride in Ophthalmic Solution. Advances in Analytica Chemistry 2: 74-79. Link: http://bit.ly/2RBDQX1

13. Bhoomendra B, Sirajunisa T, Sunil D (2014) A Validated Method for the Quantitation of Ciprofloxacin Hydrochloride Using Diffuse Reflectance Infrared Fourier Transform Spectroscopy. Int J Spectrosc. Link: http://bit.ly/2RBhKnj

14. Reem HO, Amir AS (2019) Fingerprint Spectrophotometric Methods for the Determination of Co-Formulated Otic Solution of Ciprofloxacin and Fluocinolone Acetonide in Their Challengeable Ratio. J Anal Methods Chem 2019: 14. Link: http://bit.ly/380CQVb

15. Shihn-Sheng Wu, Chih-Yuan C, Yen-Hsia W (2008) Analysis of Ciprofloxacin by a Simple High-Performance Liquid Chromatography Method. J Chromatogr Sci 46. Link: http://bit.ly/2RBolya

16. Rodrigo S, Jessica P, Juliete F, Mariana L, Mayara L (2014) Determination of Ciprofloxacin in Pharmaceutical Formulations Using HPLC Method with UV Detection. Indian J Pharm Sci 76: 541-544. Link: http://bit.ly/2U4K1EE

17. JanisV, Francesca B, Nicolette SB, Carmel S, Victor F, et al. (2015) A simple HPLC-UV method for the determination of ciprofloxacin in human plasma. $J$ Chromatogr B 989: 80-85. Link: http://bit.ly/2S2srhl

18. Ferrone V, Cotellese R, Cichella A, Raimondi P, Carlucci M, et al. (2019) Meropenem and ciprofloxacin in complicated gastric surgery for cancer patients: A simple SPE-UHPLC-PDA method for their determination in human plasma. Biomed Chromatogr 33: e4450. Link: http://bit.ly/37Ad7PX

19. Guidance for Industry (1996) Q2B Validation of Analytical Procedures: Methodology. International Conference of Harmonization (ICH). Link: http://bit.ly/2UgeTCj

\section{Discover a bigger Impact and Visibility of your article publication with} Peertechz Publications

\section{Highlights}

* Signatory publisher of ORCID

* Signatory Publisher of DORA (San Francisco Declaration on Research Assessment)

* Articles archived in worlds' renowned service providers such as Portico, CNKI, AGRIS, TDNet, Base (Bielefeld University Library), CrossRef, Scilit, J-Gate etc.

* Journals indexed in ICMJE, SHERPA/ROMEO, Google Scholar etc.

* OAI-PMH (Open Archives Initiative Protocol for Metadata Harvesting)

* Dedicated Editorial Board for every journal

* Accurate and rapid peer-review process

* Increased citations of published articles through promotions

* Reduced timeline for article publication

Submit your articles and experience a new surge in publication services (https://www.peertechz.com/submission).

Peertechz journals wishes everlasting success in your every endeavours.

Copyright: @ 2020 Zareh MM, et al. This is an open-access article distributed under the terms of the Creative Commons Attribution License, which permits unrestricted use distribution, and reproduction in any medium, provided the original author and source are credited. 